\title{
FLOOD CONTROL THROUGH STRUCTURAL AND NON-STRUCTURAL AMPLIFICATION APPROACHES (Optimization of Flood Control Efforts)
}

\author{
Ligal Sebastian \\ Permanent Lecturer of YPTP at the Civil Engineering Study Program, \\ Faculty of Engineering, University of Palembang
}

\begin{abstract}
Changes in land use along with the increase in population both in urban and rural areas, of course, are followed by problems and environmental damage, for example; flooding, garbage, and damage to drainage construction. Preventing flood disasters, it is necessary to develop strategies and control techniques for flood-affected areas (including watersheds) through structural and non-structural amplification strategies in their control. The method of approach is qualitative description and descriptive comparative case which aims to look at the flood problems that occurred in several locations from a technical and social point of view as well as strategies for handling them. In addition, a spatial analysis of the watershed area was carried out on field observation data on objects affected by flooding to determine the physical and social conditions related to flood control efforts. The government has taken various steps to overcome flooding, but it is recognized that it is still not optimal due to land suitability factors. Through structural and non-structural amplification approaches, watershed conditions can be evaluated and optimized over time according to conditions. Structural and non-structural amplification approaches are predicted to help the process of flood prevention and control more optimally. The concept of evaluating land suitability for residential areas and watershed areas, as well as the social conditions of local communities
\end{abstract}

Keywords: Flood Control, Watershed Area, Structural-Non-Structural Amplification

\section{INTRODUCTION}

The increase in the volume of surface water accompanied by runoff caused by rainfall above normal has an impact on the occurrence of inundation or flooding. This condition occurs because of land conversion activities and waste problems. The increasingly dense settlements are the cause of land use change, occurring in various areas including urban and rural areas. Based on statistical data, the percentage of the population of urban areas in Indonesia in 2020 is $56.7 \%$, while the projected developments in 2025, 2030, and 2035 are $60 \%, 63.4 \%$, and $66.6 \%$, respectively (BPS 2019). The data shows the growth of urban areas is increasing rapidly along with population growth and expansion of land use or conversion for the benefit of the residential sector and others. than the stored water (Suripin, 2001).

Changes in land use along with the increase in population both in urban and rural areas, of course, are followed by problems and environmental damage, for example; flooding, garbage, and damage to drainage construction, thus requiring a management strategy to balance the development of urban/rural areas.
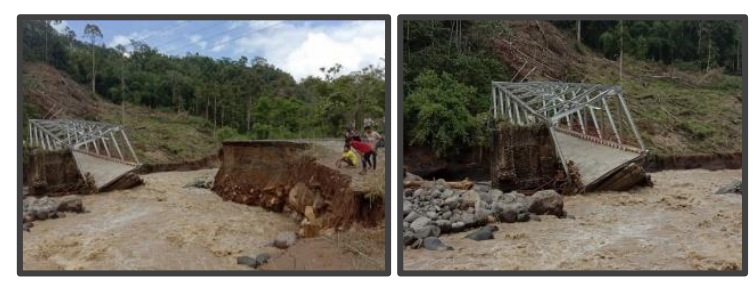

Figure 1. Damage to Mulak Ulu Bridge Construction (Link in Lahat and Muara Enim Regencies, South Sumatra). (Sumber: BPBD Sumsel, 30 Desember 2019)

Bridge and road infrastructure were also affected by the flood disaster and one of the causes was due to large land changes in the upstream area including changes in land function (Arsyad, 1989). Large water discharge currents cause erosion (erosion and abrasion) and damage to infrastructure as well as an increase in river flow discharge, In Figure 1. Damage to bridge construction on the banks of the Lematang River, Muara 
Enim Regency. This is due to the turbulent flow of the river during the flood discharge. The amount of flood discharge depends on several factors including soil conditions, climate/season changes, the condition of the ground surface being tightly covered by buildings and the loss of water catchment areas and land conversion (Asdak, 2004). To prevent flood disasters, it is necessary to develop strategies and control techniques for flood-affected areas (including watersheds) through structural and non-structural amplification strategies in flood control. This writing aims to describe flood control efforts through the development and combination of structural and non-structural based on the evaluation of land suitability so that it is expected to reduce or minimize the impact of floods that occur.

\section{METHODOLOGY AND THEORY}

This article is written based on a study that uses a qualitative descriptive approach and a descriptive comparative case that aims to look at the flood problems that occurred in several locations from a technical and social point of view as well as strategies for handling them. In addition, a spatial analysis of the watershed area was carried out on field observation data on objects affected by flooding to determine the physical and social conditions related to flood control efforts. The study activity was carried out by field observations of flood/post-flood affected locations which were then used as basic assumptions to explain the need for optimizing efforts to handle and control floods. After conducting observations, then supplemented by data obtained from documents or other sources related to flood control. The data collection technique was carried out by purposive cases at locations that had experienced flooding in several watersheds (DAS), including in Palembang City and Lahat Regency which borders Muara Enim Regency, South Sumatra Province.

Optimization of flood control strategies is needed in line with the magnitude of the potential damage that occurs in residential areas and along the watershed. Although flood prevention efforts have been carried out, it is estimated that they have not considered the concept of land suitability evaluation. Structural and non-structural amplification approaches are one of the optimization efforts that combine flood potential control techniques based on land suitability evaluation, including in the watershed (DAS) environment. Technically, structural amplification is carried out through the determination and construction of micro retention ponds, construction of main box drainage, location determination and construction of micro embankments and plant revegetation. Meanwhile, non-structural amplification is carried out through educative, communicative and persuasive approaches.

\section{RESULTS AND DISCUSSION}

Flood control is closely related to the management of water and land resources, including the management of solid waste or waste. The factors of high rainfall, topographic and physiographic conditions, erosion and sedimentation, and the influence of tidal water are very influential. In addition, due to human activities causing environmental changes include; watershed conditions, riverbank areas, and damaged drainage. Changes in watershed conditions include; deforestation (illegal logging), shifting gardens/farming and forest reforestation games for business are one of the causes for the disruption of natural catchment areas and the hydrological cycle. Urban development and land changes have an impact on flooding and causing damage to infrastructure construction, among others; bridges, buildings, drainage canals, and other facilities.

The conditions affected by the damage are shown in Figures 2, 3 and 4.

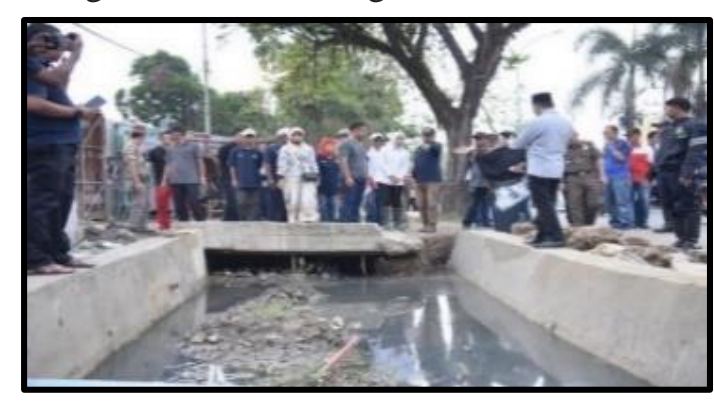

Figure 2.

Post-Flood Drainage Sedimentation

(Sumber: Sripo, 26/01/2021, Kec. Sako Palembang) 


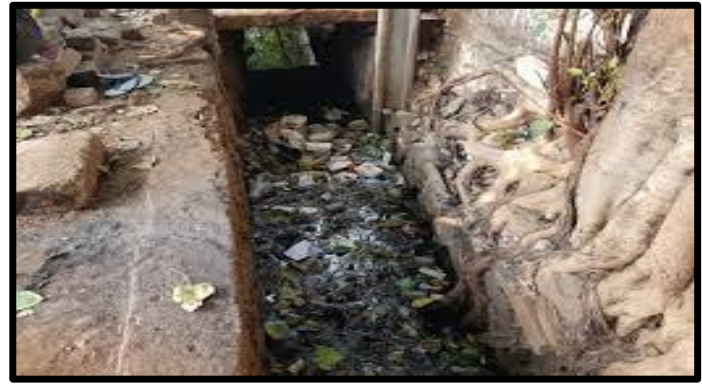

Figure 3

Drainage Damage and Garbage

(Sumber: Palpos, 2/12/2019, Kec. Sukarami Palembang)

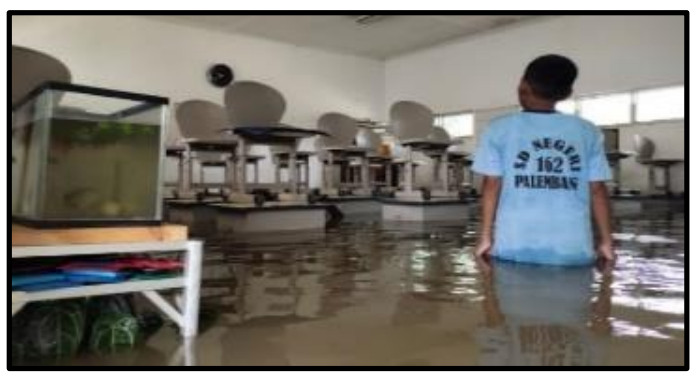

Figure 4.

Flood-affected school conditions

(Sumber: Palpos,19/12/2019, Kec.Kemuning Palembang)

Analysis of the frequency of flooding, mapping/zoning, evaluation of events and damage, on river flows continues. Riverbanks and embankments/equivalents may not be converted for physical development and settlements, so relevant stakeholders must pay attention to urban areas by guiding land use arrangements and their utilization according to spatial functions.

\section{Flood Control Efforts}

The government has taken various steps in overcoming floods, but it is acknowledged that they are still not optimal due to the land suitability factor which is the focus of this study. Land suitability is the level of suitability of land for certain uses. Land suitability can be assessed for current conditions (actual land) or after improvement (potential land) for both residential land and watersheds. Through structural and nonstructural amplification approaches, watershed conditions can be evaluated and optimized over time according to conditions. Structural amplification is carried out through the improvement and arrangement of the watershed system which includes the construction/development of natural/artificial small-scale holding ponds, construction of small-scale flood control drainage, smallscale embankments and reforestation/revegetation. Optimization of capacity building for flood control infrastructure in the form of dredging/normalization is carried out when silting/sedimentation occurs to increase the capacity of water runoff storage. In Figures 5(a) and 4(b) based on the structural amplification process, it can be seen that in areas/settlement areas/urban centers, infrastructure optimization can be done; retention ponds, optimization of artificial channels (drainage), rain harvesting, biopori, repair of lakes. The integrated planning technique is through the stages of evaluating land suitability by combining the techniques of determining drainage design, determining river commensurate embankments, making in situ/situ ponds and determining the location of revegetation/green barriers.

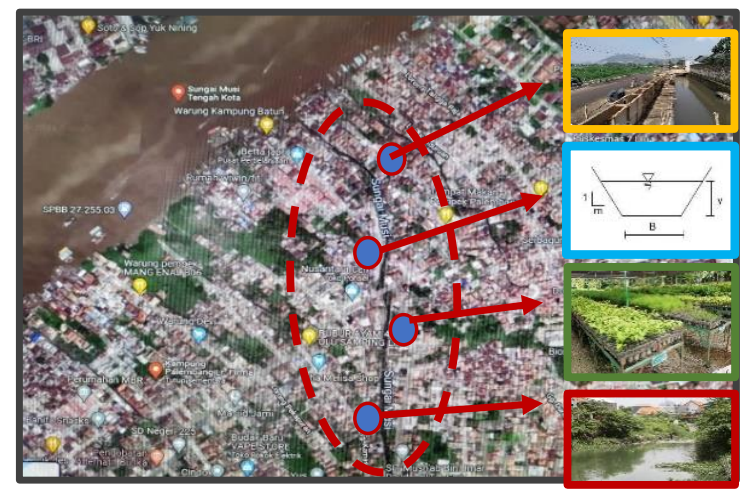

a. Structural and Non-Structural Amplification in Palembang City, 2021 Source:Google.com.Photo Udara.Palembang.Kec.SU I, Palembang)

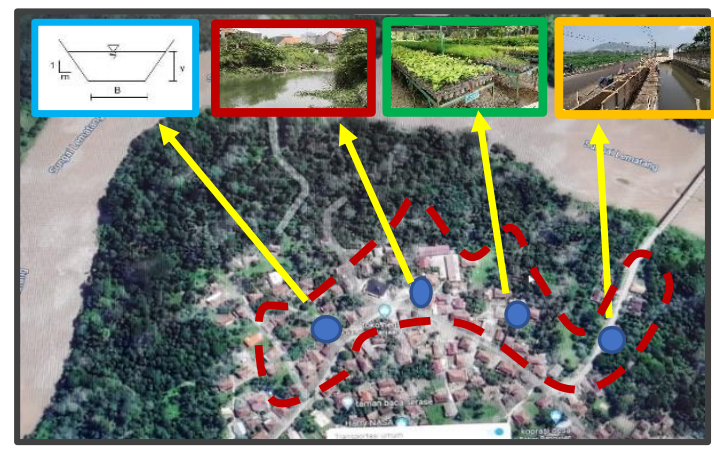

b. Structural and Non-Structural Amplification in Lahat District, 2021 (Source: Google.com. Aerial Photos. Kec. Merapi Timur Kab. Lahat)

Figure 5.

Structural Amplification of Musi and Lahat Watersheds 
Structural amplification can be done, including; construction of small-scale ponds, construction of main box drainage, flood embankments and reforestation of riverbanks/mini green barriers. This activity is based on the concept of evaluating land suitability by considering the environmental carrying capacity factor as well as a map of watershed infrastructure from the upstream, middle and downstream areas of the river, both in urban and rural areas. Non-structural amplification is carried out on elements of local/local communities (Figure 5 red line zoning) through evaluation and mapping of flood-prone areas, determination of flood routes, early warning systems, emergency response and vegetative soil conservation and watershed conservation (DAS) as well as community empowerment. through community movements (youth/customary leaders) aware of flood disasters, improvement of river channels and channels, waste control, and reforestation of riverbanks, as well as preserving the environment.

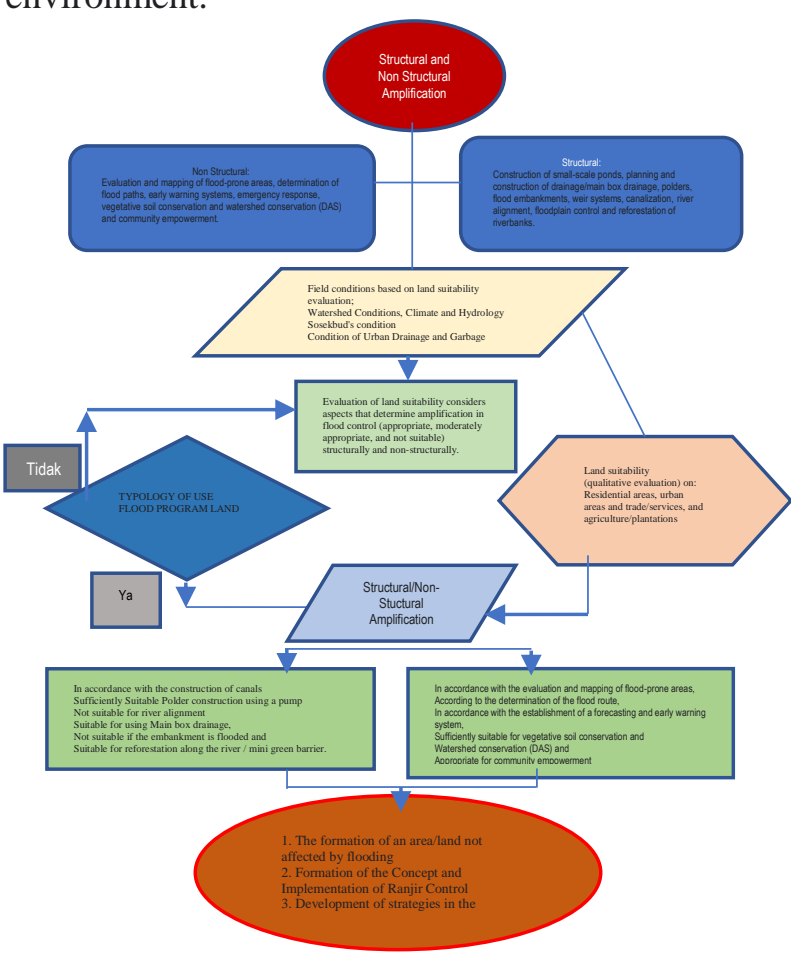

Figure 6. Mechanism of Flood Management with S/NS . Amplification

\section{CONCLUSIONS AND SUGGESTIONS}

Structural and non-structural amplification approaches are predicted to help the process of flood prevention and control more optimally. The concept of evaluating land suitability for residential areas and watershed areas, as well as the social conditions of local communities is a guide in the structural and non-structural amplification approaches. The dynamics of change and use of land functions that are not in line with the spatial and regional patterns of each region, have a very negative effect on regional conditions, including in watersheds (DAS). Changes in the dominant land use conditions cause environmental damage, including floods. It is hoped that the structural amplification approach can improve the control and drainage capacity of watersheds in the upstream, middle and downstream areas of the river. Meanwhile, the non-structural amplification approach is through community empowerment strategies to be aware of protecting the environment based on local wisdom and behavior, and protecting watersheds in a sustainable manner. In addition, it is still necessary to optimize nonstructural amplification in flood control in the form of flood alert villages through a sociological approach to empowerment programs, guidance / counseling / disaster response training and socialization involving the role of youth leaders, traditional leaders and local / local religious leaders on an ongoing basis. With the above program, it will become a medium to increase public awareness and understanding of flood disasters and their causes, as well as their impact on humans. Success in overcoming flood problems can be achieved if it is supported by synergy, understanding attitudes and togetherness of multistakeholders and community involvement.

\section{REFERENSI}

Agus, 2021. Pengelolaan Kawasan Sempadan Sungai. UGM Press.

Arsyad, 1989. Konservasi Tanah dan Air. Penerbit IPB. Bandung. 
Asdak, 2004. Hidrologi dan Pengelolaan Daerah Aliran Sungai. UGM Pres. Yogyakarta.

Badan Pusat Statistik. 2019. Jumlah Penduduk Indonesia. Jakarta: BPS.

Kodoatie, Robert J. dan Sugiyanto, 2002. Banjir, Beberapa Penyebab dan Metode Pengendaliannya dalam Perspektif Lingkungan, PP, Yogyakarta.

Mulyanto, 2007. Sungai, Fungsi dan SifatSifatnya. Graha Ilmu. Yogyakarta.

Sebastian, L. 2018. Pendekatan Pencegahan dan Penanggulangan Banjir. FTS Unpal.

Suripin, 2001. Pelestarian Sumber Daya Tanah dan Air. Penerbit Andi Offset.

https://databoks.katadata.co.id/datapublish/20 21/08/18/sebanyak-567-pendudukindonesia-tinggal-di-perkotaan-pada2020

https://daerah.sindonews.com/berita/1491757 /174/3-kecamatan-di-kota-lahatditerjang-banjir-bandang

https://palembang.tribunnews.com/2021/01/2 6/dengar-jeritan-warga-wakilwalikota-tinjau-perumahan-bsbwarga-berharap-segera-ada-solusi

https://palpos.id/2019/12/19/12-lokal-sdn162-palembang-terendam-banjir/

https://palpos.id/2019/12/02/kabel-sampahdan-pipa-tutupi-drainase-hinggabanjir/

https://regional.kompas.com/read/2019/12/30 /11424801/diterjang-banjir-jembatanpenghubung-lahat-muara-enimambruk

https://sumsel.inews.id/berita/diguyur-hujanlebat-longsor-dan-banjir-bandangterjang-3-kecamatan-di-lahat

https://www.google.com/maps/search/foto+u dara+kota+palembang/@ $3.0013719,104.7596434,1886 \mathrm{~m} /$ data $=! 3 \mathrm{~m} 1 ! 1 \mathrm{e} 3 ? \mathrm{hl}=\mathrm{id}$

https://www.google.com/maps/search/foto+u dara+Kabupaten+Muara+Enim/@ $3.6364506,103.7054349,816 \mathrm{~m} /$ data $=$ ! $3 \mathrm{~m} 1$ ! $1 \mathrm{e} 3$ ?hl=id

https://www.scribd.com/document/24838666 3/Pengendalian-Banjir-Terpadu. 